\title{
The differential mental health impact of COVID-19 in Arab countries
}

\author{
Hanaa A.M. Shuwiekh ${ }^{1} \cdot$ Ibrahim A. Kira ${ }^{2,3}$ (D) Mariam Sous Fahmy Sous ${ }^{4} \cdot$ Jeffrey S. Ashby $^{3} \cdot$ Amthal Alhuwailah $^{5}$. \\ Shadia Bint Ali Baali ${ }^{6}$. Chafika Azdaou ${ }^{7}$. Enas M. Oliemat ${ }^{8} \cdot$ Hikmet J. Jamil $^{9}$
}

Accepted: 22 October 2020 / Published online: 2 November 2020

(C) Springer Science+Business Media, LLC, part of Springer Nature 2020

\begin{abstract}
COVID-19 pandemic's mental health impact on Arab countries is under-researched. The goal of this investigation was to study the differential impact of COVID-19 on the mental health of Arab countries. A questionnaire including measures of COVID-19 traumatic stress, PTSD, depression, anxiety, and cumulative stressors and trauma was distributed anonymously online in seven Arab countries (Egypt $(N=255)$, Kuwait $(N=442)$, Jordan $(N=216)$, Saudi Arabia $(N=212$, Algeria $(N=110)$, Iraq and Palestine $(N=139))$. We used ANOVA and stepwise regression to analyze the data. For each country, regression, PTSD, depression, and anxiety were dependent variables; we entered in the first-step, gender, age, religion, education, and income. In the second step, we entered "cumulative stressors and traumas." In the third step, we entered COVID-19 traumatic stress. The ANOVA results indicated that the differences in COVID19 traumatic stress, PTSD, depression, and anxiety between the countries were significant. Post-hoc analysis indicated that Egypt is significantly higher than all the other Arab countries in COVID-19 traumatic stress, PTSD, anxiety, and depression. The subsample from Palestine and Iraq had a significantly higher cumulative trauma load than the other Arab countries but did not have higher levels of COVID-19 traumatic stress or PTSD. Stepwise regression indicated that COVID-19 traumatic stress accounted for significant variance above and beyond the variance accounted for by previous cumulative stressors and traumas for anxiety in all countries and PTSD and depression in all countries except for Algeria. We discussed the implications for these results for the urgent mental health needs of Arab countries.
\end{abstract}

Keywords COVID-19 $\cdot$ PTSD $\cdot$ Arab countries and MENA region · Mental health

Electronic supplementary material The online version of this article (https://doi.org/10.1007/s12144-020-01148-7) contains supplementary material, which is available to authorized users.

Ibrahim A. Kira

kiraaref@aol.com

Hanaa A.M. Shuwiekh

has11@fayoum.edu.eg

Mariam Sous Fahmy Sous

mariamsous2020@gmail.com

Jeffrey S. Ashby

jashby2@gsu.edu

Amthal Alhuwailah

al_huwailah77@hotmail.com

Shadia Bint Ali Baali

lagoona15@gmail.com

Chafika Azdaou

chafika.azdaou@univ-alger2.dz

Enas M. Oliemat

Enass@hu.edu.jo
Hikmet J. Jamil

hikmet.jamil@hc.msu.edu; hikmet1935@gmail.com

Fayoum University, Fayoum, Egypt

2 Center for Cumulative Trauma Studies, 4906 Woodhurst Way, Stone Mountain, GA 30088, USA

3 Affiliate of Center for Stress, Trauma and Resiliency, Georgia State University, Atlanta, GA, USA

4 South Valley University, Qena, Egypt

5 Kuwait University, Kuwait, Kuwait

6 Psychological compatibility center for Psychological counseling, Riad, Saudi Arabia

7 University of Algiers, Algiers, Algeria

8 Hashemite University, Zarqa, Jordan

9 Department of Family Medicine, Michigan State University, Lancing, Michigan, USA 


\section{Introduction}

COVID-19 pandemic's socioeconomic and mental health impacts are unprecedented, with worldwide economic loss, travel restrictions, closure of business activities, social distancing, isolation and quarantine, and fear of shortage of basic needs (e.g., McKibbin \& Fernando, 2020; Ornell, Schuch, Sordi, \& Kessler, 2020; Palgi et al., 2020; Porcelli, 2020; Usher, Bhullar, \& Jackson, 2020). Sources of COVID-related distress include constant fear of contracting the virus, actually contracting the virus, losing loved ones to the illness, and being socially isolated or quarantined. These factors can precipitate mental health problems in those with no previous mental health history or exacerbate symptoms in those with pre-existing mental health problems. COVID-19 traumatic stress constitutes a new type of traumatic stress that has at least three components: the constant threat/fear of contracting the virus, the economic loss, for example, loss of business or job, and disturbed routines, and isolation (Kira et al., 2020b).

COVID-19 traumatic stress is a new type of traumatic stress. In other trauma types, we can identify and control the perpetrator through the law and other legal means but controlling the virus (COVID 19) depends on medical science and measures of social and political policies and will. Further, COVID-19 is a continuous ongoing traumatic stress. It is a type III trauma (i.e., still ongoing), which is a more severe form of traumatic stress (Kira et al., 2008). No data are indicating when it will stop or on its long term impact. Prominent formulations of traumatic stress retain the assumption that traumas have occurred in the past, disregarding traumatic stress that may be ongoing and continue into the future (Eagle \& Kaminer, 2013; Kira et al., 2013a). However, several studies (e.g., Goral, Lahad, \& Aharonson-Daniel, 2017; Kira, Ashby, et al., 2013a) have found that when a traumatic experience is present and ongoing, posttraumatic stress disorder symptoms become more significant and severe.

One distinctive of the experience of COVID-19 is that a person's fears are more focused on the present or the future. Time perspective and anticipation, and not the past, is the primary focus. The person has a realistic fear and anticipation of being a present or future victim. This anticipation is particularly salient as research has suggested that a present or future negative time perspective is the strongest predictor of perceived distress (Rönnlund, Åström, Adolfsson, \& Carelli, 2018). Further, COVID-19 consists of multiple complex traumas. COVID-19 traumatic stress includes at least three main threats (Kira, Shuwiekh, et al., 2020b): threat/fear of the present and future infection and potential subsequent death (e.g., Ornell et al., 2020; Porcelli, 2020), the actual economic hardship (e.g., McKibbin \& Fernando, 2020), and the stressors and traumatic stressors related to the disturbed life routines, isolation, and family and social life (Brooks et al., 2020; Palgi et al., 2020; Usher et al., 2020). Additionally,
COVID-19 is a mass collective and global pandemic. It may affect everybody everywhere, either directly or indirectly, through secondary stress and traumatization dynamics and media and social media.The COVID-19 pandemic has impacted the planet and had a profound effect across all inhabited continents. One of the regions where the mental health impact of COVID-19 has received little research attention is the Middle East and North Africa (MENA) and Arab countries. It is important to explore this outbreak's influence on mental health in this region as it is area that is often neglected.

Due to a variety of factors, COVID-19 is under-reported in most Arab countries (e.g., Tuite et al., 2020). As a result, measuring its psychological impact can offer some additional information. While investigations of the psychological impact of COVID-19 in Arab countries is limited, a recent study on the potential mental health impact of COVID-19 in an Egyptian sample found that $41.4 \%$ of the sample scored on the high end of a measure for PTSD (El-Zoghby, Soltan, \& Salama, 2020). However, the study did not control for other stressors and, as a result, it is impossible to determine if PTSD symptoms should be attributed to the experience of COVID19 or to other pre-COVID-19 stressors or traumas.

The Arab world (pre-COVID-19) has gone through several historical traumas. These include the Arab Israeli conflict (e.g., Sayigh, 2013; Schulze, 2016) and Iraqi gulf wars (e.g., Heidenrich, 1993; Wehrey, 2013) in addition to Arab Spring and Arab-Winter (e.g., Dabashi, 2012; Kurzman, Fahmy, Gengler, Calder, \& Whitson, 2013) and the Syrian and Libyan civil wars (Kira, Shuwiekh, Rice, Al Ibraheem, \& Aljakoub, 2017; Kira, Shuwiekh, Al Ibraheem, \& Aljakoub, 2019d). Further, the Arab world is currently going through political turmoil and economic crises that overlap with COVID-19 continuous traumatic stress. These national collective traumatic factors are added to the individual factors that each individual in the region may have endured.A number of different factors affect the spread of COVID-19 and its subsequent mental health impact, including population density, the economic and income level, and age. The study of the spatial epidemic dynamics of COVID-19 spread in China (Kang, Choi, Kim, \& Choi, 2020) and the spatial diffusion process of SARS (Meng, Wang, Liu, Wu, \& Zhong, 2005) showed that population density was more significant than the population size in their spread, although both were important. For Arab countries, Egypt has the highest population density compared to Saudi Arabia and Algeria, especially larger cities (e.g., Barr \& Tassier, 2020; Tabutin, Schoumaker, Rogers, Mandelbaum, \& Dutreuilh, 2005).

Income is another critical economic and demographic factor in COVID-19 impact. For example, Walker et al. (2020) found in their computer model of worldwide COVID-19 impact that lower-income countries showed significantly more death from the virus. One of the critical impacts of COVID-19 
traumatic stress is economical (e.g., McKibbin \& Fernando, 2020). The economic impact of COVID-19 goes beyond morbidity and mortality resulting from the virus to the disruption of global and local economies' functioning. Many companies across the world, irrespective of size, have experienced significant contractions in production. Service-oriented economies are significantly negatively affected. Countries like Egypt that are more reliant on tourism (more than 15\% of GDP), and those that are more reliant on oil, like Saudi Arabia, are more affected by this crisis. Countries highly dependent on foreign trade (most or all Arab countries) are also more negatively affected (e.g., McKibbin \& Fernando, 2020).

Another demographic factor related to the COVID-19 threat is age. Older age is associated with more death from COVID-19 than younger or middle-aged groups (Zhou, Snoswell, et al., 2020a; Zhou, Yu, et al., 2020b). Additional effects of COVID-19 also appear to be age-dependent. Rates of hospitalization and death are less than $0.1 \%$ in children but increase to $10 \%$ or more in older people (Promislow, 2020). The COVID-19 mortality risk is highly concentrated at older ages, particularly those aged $80+$ years. In China, the case fatality rate estimates ranged from $0.4 \%$ for 40 to 49 year-olds, jumping to $14.8 \%$ for those $80+$ years. The fatality age pattern had been starker in Italy, where, as of March 30, 2020, the reported fatality rate was $0.7 \%$ for those aged 40 to 49 , and $27.7 \%$ for those older than 80 , with $96.9 \%$ of deaths occurring in those aged 60 years and over (Dowd et al., 2020). While older age appears to be a significant risk factor for the severity of COVID-19 symptoms, it does not appear to be a risk factor for the potential infection of COVID-19 or its potential mental health-related symptoms. As Palgi, Shrira, and Shmotkin (2015) have noted, the elderly may be vulnerable or resilient and may have developed sufficient coping skills from previous and ongoing traumas and loss.

The purpose of this study was to measure the differential COVID-19 mental health impact, over and beyond the impact of previously experienced trauma. Specifically, we gathered data from different Arab countries intending to differentiate the impact of COVID-19 as a new added, ongoing, and developing traumatic stress, separate from all other previous and concurrent collective and individual stressors and traumas that may be different in its spread and mental health impact for each Arab country.

\section{Research Questions}

1. What are the differences between Arab countries in the impact of COVID-19 traumatic stress mental health after controlling for the impact of previous cumulative stressors and trauma?

2. Does COVID-19 traumatic stress account for unique significant variance above and beyond the variance accounted for by cumulative stressors and traumas for
PTSD, Depression, and Anxiety in samples from each Arab country?

\section{Research Hypotheses}

Hypothesis 1 The more densely populated Arab countries that are more vulnerable to the spread of the disease will show greater COVID-10 related mental health impact, regardless of their previous level of exposure to stressors and traumas.

Hypothesis 2 Income can be potentially a protective factor against the mental health impact of COVID-19, regardless of their previous level of exposure to stressors and traumas, as the economic impact of COVID-19 is one of the critical stressors that impact the individual's mental health.

Hypothesis 3 Old age can be protective or risk factors for the mental health impact of COVID-19.

\section{Methods}

\section{Procedure}

Three core researchers developed the initial English version of the COVID-19 questionnaire from two centers that study stress, trauma, and cumulative traumas in the United States. The questionnaire included measures of COVID-19 as traumatic stress, PTSD, anxiety, cumulative stressors, and traumas, among other measures. The Arabic version of the questionnaire was translated and back-translated and culturally adapted by a researcher at Fayoum University, Egypt. The team used Google Drive and developed a survey link. The collaborating professionals in different Arab countries followed the chain recruiting method in collecting data from their respective countries by emailing the survey link to their contacts and asking the contacts, after completing the questionnaire, to email the survey link to their contacts to participate and subsequently send on to contacts with the same request. Once the participant completed the survey, it was sent anonymously to Gmail and then downloaded to an Excel file. All questionnaires were answered individually by participants from $4 / 28 / 2020$ to $5 / 25 / 2020$. Participation was voluntary; each person took approximately $25 \mathrm{~min}$ to complete the full questionnaire. The Fayoum University IRB approved the research as a cross-cultural study of the COVID-19 mental health impact.

\section{Participants}

One thousand and three hundred seventy-four $(N=1374)$ adult participants were recruited from seven Arab countries 
(Egypt, Kuwait, Saudi Arabia, Jordan, Algeria, Iraq, and Palestine). Because the number of participants from Palestine $(N=72)$ and Iraq $(N=67)$ was relatively small, and the initial analysis indicated that they are similar regarding their trauma load; also, they live under similar circumstances of internal and external conflicts, we combined the participants from the two countries in one subsample $(N=139)$. Table 1 summarizes the characteristics of the subsamples.

\section{Measures}

COVID-19 Traumatic Stress Scale (Kira, Shuwiekh, et al., 2020b) The COVID-19 traumatic stress scale is a 12-item scale including three subscales "threat/fear of the present and future infection and death" (5 items), "traumatic economic stress" (4 items), and "isolation and disturbed routines" (3 items). Items are scored on 5 point Likert-scale, with (1) indicating not at all and (5) very much. Examples of items include, "How concerned are you that you will be infected with the coronavirus?" "The Coronavirus (COVID-19) has impacted me negatively from a financial point of view." "Over the past two weeks, I have felt socially isolated due to the coronavirus." In the initial study (Kira, Shuwiekh, et al., 2020b), the scale showed good construct convergent-divergent and predictive validity. The COVID-19 scale had an alpha of .88 in the current study and. Its three Subscales had Cronbach alphas of $.84, .75$, and .70 , respectively.

Cumulative Stressors and Traumas Scale (CTS-S-36 Items) (Kira et al., 2008) The CTS-S-36 scale was designed to measure seven types of stressors/traumas (collective identity trauma, personal identity trauma, identity/achievement trauma, survival trauma, attachment trauma, secondary trauma, and gender discrimination). Additionally, the scale includes three items that measure chronic and significant life stressors. Example items for the collective identity traumas (e.g., discrimination and oppression) include: "I have been discriminated against because of my sexual preference." A personal identity trauma (e.g., early childhood traumas such as child neglect and abuse) example is: "I was led to have sexual

Table 1 Demographics of the subsamples

\begin{tabular}{|c|c|c|c|c|c|c|}
\hline Variable & Egypt $N=255$ & uwait $N=442$ & Jordan $N=216$ & Algeria $\mathrm{N}=110$ & $\begin{array}{l}\text { Iraq and Palestine } \\
\mathrm{N}=139\end{array}$ & $\begin{array}{l}\text { Saudi Arabia } \\
\mathrm{N}=212\end{array}$ \\
\hline ge & $\begin{array}{l}\mathrm{M}=24.27 \\
\mathrm{SD}=6.77 \\
(18-55)\end{array}$ & $\begin{array}{l}M=27.11 \\
S D=11.29 \\
(18-75)\end{array}$ & $\begin{array}{l}M=28.76 \\
S D=10.67 \\
(18-60)\end{array}$ & $\begin{array}{l}M=40.99 \\
S D=12.47 \\
(18-70)\end{array}$ & $\begin{array}{l}M=42.40 \\
S D=13.11 \\
(18-70)\end{array}$ & $\begin{array}{l}M=41.25 \\
S D=11.18 \\
(18-65)\end{array}$ \\
\hline ender & $78.8 \%$ Females & $\begin{array}{l}89.6 \% \\
\text { Females }\end{array}$ & $\begin{array}{l}88.4 \% \\
\text { Females }\end{array}$ & $\begin{array}{l}82.7 \% \\
\text { Females }\end{array}$ & $\begin{array}{l}55.4 \% \\
\text { Females }\end{array}$ & $\begin{array}{l}80.7 \% \\
\text { Females }\end{array}$ \\
\hline Religion & $\begin{array}{l}\text { 79.6\% Muslims and } \\
\text { 20.4\% Christians }\end{array}$ & $\begin{array}{l}99.5 \% \text { Muslims, } \\
.05 \% \text { Christians }\end{array}$ & $\begin{array}{l}\text { 90.7\% Muslims, } \\
\text { 9.3\% Christians }\end{array}$ & $\begin{array}{l}99.1 \% \text { Muslims, } .9 \% \\
\text { Christians }\end{array}$ & $\begin{array}{l}\text { 91.4\% Muslims, } \\
\text { 8.6\% Christians }\end{array}$ & $\begin{array}{l}99.5 \% \text { Muslims, } \\
.05 \% \text { Christians }\end{array}$ \\
\hline Education & $\begin{array}{l}1.2 \% \text { reading and } \\
\text { writing level, } \\
2.7 \% \text { middle to } \\
\text { the high school } \\
\text { level, } 72.5 \% \\
\text { college level, and } \\
23.5 \% \text { graduate } \\
\text { studies level }\end{array}$ & $\begin{array}{l}.07 \% \text { reading and } \\
\text { writing level, } \\
5.02 \% \text { middle to } \\
\text { the high school } \\
\text { level, } 75.6 \% \\
\text { college level, and } \\
18.6 \% \text { graduate } \\
\text { studies level }\end{array}$ & $\begin{array}{l}.09 \% \text { reading and } \\
\text { writing level, } \\
2.08 \% \text { middle to } \\
\text { the high school } \\
\text { level, } 70.08 \% \\
\text { college level, and } \\
25.5 \% \text { graduate } \\
\text { studies level }\end{array}$ & $\begin{array}{l}.09 \% \text { reading and } \\
\text { writing level, } \\
7.3 \% \text { middle to } \\
\text { the high school } \\
\text { level, } 68.2 \% \\
\text { college level, and } \\
23.6 \% \text { graduate } \\
\text { studies level }\end{array}$ & $\begin{array}{l}2.2 \% \text { reading and } \\
\text { writing level, } 5 \% \\
\text { middle to the high } \\
\text { school level, } \\
46.8 \% \text { college } \\
\text { level, and } 46 \% \\
\text { graduate studies } \\
\text { level }\end{array}$ & $\begin{array}{l}2.8 \% \text { reading and } \\
\text { writing level, } \\
7.1 \% \text { middle to } \\
\text { the high school } \\
\text { level, } 68.9 \% \\
\text { college level, and } \\
21.2 \% \text { graduate } \\
\text { studies level }\end{array}$ \\
\hline $\begin{array}{l}\text { Marital } \\
\text { Status }\end{array}$ & $\begin{array}{l}78 \% \text { single } 20 \% \\
\text { married, } 1.2 \% \\
\text { widowed, } .8 \% \\
\text { divorced }\end{array}$ & $\begin{array}{l}65.8 \% \text { single } 28.1 \% \\
\text { married, } 5.9 \% \\
\text { widowed, } .2 \% \\
\text { divorced }\end{array}$ & $\begin{array}{l}68.1 \% \text { single } 28.7 \% \\
\text { married, } 2.3 \% \\
\text { widowed, } .9 \% \\
\text { divorced }\end{array}$ & $\begin{array}{l}31.8 \% \text { single } 63.6 \% \\
\text { married, } 3.6 \% \\
\text { widowed, } .9 \% \\
\text { divorced }\end{array}$ & $\begin{array}{l}29.5 \% \text { single } 63.6 \% \\
\text { married, } 4.3 \% \\
\text { widowed, } 2.9 \% \\
\text { divorce }\end{array}$ & $\begin{array}{l}18.4 \% \text { single } 69.3 \% \\
\quad \text { married, } 8 \% \\
\text { widowed, } 4.2 \% \\
\text { divorce }\end{array}$ \\
\hline Employment & $\begin{array}{l}11.8 \% \text { work with the } \\
\text { government, } 6.3 \% \\
\text { private business, } \\
69.4 \% \text { Students, } \\
12.2 \% \text { retired, and } \\
.4 \% \text { unemployed }\end{array}$ & $\begin{array}{l}25.1 \% \text { work with the } \\
\text { government, } 4.1 \% \\
\text { private business, } \\
65.4 \% \text { Students, } \\
2.7 \% \text { retired, and } \\
2.7 \% \text { unemployed }\end{array}$ & $\begin{array}{l}16.2 \% \text { work with the } \\
\text { government, } \\
23.6 \% \text { private } \\
\text { business,, } 50.9 \% \\
\text { Students, } 8.3 \% \\
\text { retired, and .9\% } \\
\text { unemployed }\end{array}$ & $\begin{array}{l}65.5 \% \text { work with the } \\
\text { government, } \\
13.6 \% \text { private } \\
\text { business, } 14 . .5 \% \\
\text { Students, } 5.5 \% \\
\text { retired, and .9\% } \\
\text { unemployed }\end{array}$ & $\begin{array}{l}42.4 \% \text { work with the } \\
\text { government, } 18 \% \\
\text { private business, } \\
20.1 \% \text { Students, } \\
10.1 \% \text { retired, and } \\
9.4 \% \text { unemployed }\end{array}$ & $\begin{array}{l}36.8 \% \text { work with the } \\
\text { government, } \\
17.9 \% \text { private } \\
\text { business, } 7.5 \% \\
\text { Students, } 26.4 \% \\
\text { retired, and } \\
.11 .3 \% \\
\text { unemployed }\end{array}$ \\
\hline SES & $\begin{array}{l}0 \% \text { very low, } 24 \% \\
\text { low, } 84.3 \% \text { in the } \\
\text { middle, } 12.9 \% \\
\text { high, } .4 \% \text { very } \\
\text { high }\end{array}$ & $\begin{array}{l}0 \% \text { very low, } .07 \% \\
\text { low, } 67.9 \% \text { in the } \\
\text { middle, } 29.2 \% \\
\text { high, } 2.3 \% \text { very } \\
\text { high }\end{array}$ & $\begin{array}{l}0 \% \text { very low, } 3.7 \% \\
\text { low, } 86.1 \% \text { in the } \\
\text { middle, } 10.2 \% \\
\text { high, } 0 \% \text { very high }\end{array}$ & $\begin{array}{l}0 \% \text { very low, } .09 \% \\
\text { low, } 89.1 \% \text { in the } \\
\text { middle, } 10 \% \text { high, } \\
0 \% \text { very high }\end{array}$ & $\begin{array}{l}.7 \% \text { very low, } .7 \% \\
\text { low, } 77.7 \% \text { in the } \\
\text { middle, } 19.4 \% \\
\text { high, } 1.4 \% \text { very } \\
\text { high }\end{array}$ & $\begin{array}{l}0 \% \text { very low, } .9 \% \\
\text { low, } 63.2 \% \text { in the } \\
\text { middle, } 35.4 \% \\
\text { high, } 1.4 \% \text { very } \\
\text { high }\end{array}$ \\
\hline
\end{tabular}


contact with a person who was older than me (when I was young.)". An example of a status identity/achievement trauma (e.g., failed business, fired, and drop out of school; noncriterion A traumas) is: "I have been fired, terminated, laid off suddenly, or have had a failed business." A survival trauma (e.g., combat experience, car accidents, and natural disasters) example item is: "I have experienced a life-threatening medical condition (e.g., cancer, stroke, serious chronic illness, major injury, etc.)." As indicated above, the scale also includes items related to attachment trauma (e.g., abandonment by parents), secondary trauma (i.e., indirect trauma impact on others), and gender discrimination by parents and society. The CST-S evaluates cumulative stressors and traumas by measuring their occurrence, frequency, type, negative and positive appraisal, and chronological age at the first event. However, in the present study, we used only trauma occurrence (whether a trauma had occurred for a participant) and frequency, measured on a 5 -point Likert-type scale $(0=$ never; $5=$ many times). The CST-S has shown adequate internal consistency $(\alpha=.85)$, and test-retest stability (.95 in 4 weeks), and predictive, convergent, and divergent validity in several different studies (e.g., Bedoya et al., 2020; Eltan, 2019; Head, Singh, \& Bugg, 2012; Kira et al., 2018a; Kira et al., 2019b; Kira, Barger, Shuwiekh, Kucharska, \& Al-Huwailah, 2019a; Kira, Barger, Shuwiekh, Kucharska, \& Al-Huwailah, 2020a; Kira, Fawzi, \& Fawzi, 2013b; Robles, Badosa, Roig, Pina, \& Feixas Viaplana, 2009). The measure has been translated and validated in several languages, including Arabic, Polish, Spanish, Turkish, Korean, Burmese, and Yoruba. In the present analysis, we used the cumulative stressors and traumas occurrence sub-scale. The current alpha of cumulative stressors, as measured by traumas occurrence, was .89 .

Posttraumatic Stress Disorder Checklist for DSM-5 (PCL- V) (Blevins, Weathers, Davis, Witte, \& Domino, 2015) The PCL$\mathrm{V}$ is a 20-item self-report measure. Each item is scored on a five-point scale with " 0 ," indicating "not at all" and 4 indicating "extremely." Initial research suggests that a PCL-5 cut-off score between 31 and 33 is indicative of PTSD. A provisional PTSD diagnosis can be made by treating each item rated as 2 = "Moderately" or higher as a symptom endorsed, then following the DSM-5 diagnostic rule, which requires at least: $1 \mathrm{~B}$ item (questions 1-5), $1 \mathrm{C}$ item (questions 6-7), $2 \mathrm{D}$ items (questions 8-14), $2 \mathrm{E}$ items (questions 15-20). The Arabic version of the PCL-V has been previously validated in Arabic samples (Ibrahim, Ertl, Catani, Ismail, \& Neuner, 2018). Cronbach's alpha reliability of the scale in the current study was .94.

Generalized Anxiety Disorder-7 (GAD-7) (Spitzer, Kroenke, Williams, \& Lowe, 2006) The GAD-7 is a 7-item self-report questionnaire that assesses general anxiety. Items are scored on a 4-point scale with (0) indicating "does not exist," and (3) indicating "nearly every day." The scores range between 0 and 21 , with a cut-off point of 15 , indicating severe GAD. The GAD-7 has a sensitivity of $89 \%$ and a specificity of $82 \%$. Increasing scores on the scale have been strongly associated with multiple domains of functional impairment (Spitzer et al., 2006). The Arabic version of the GAD-7 was previously validated in Arabic samples (Sawaya, Atoui, Hamadeh, Zeinoun, \& Nahas, 2016). Cronbach's alpha reliability for the scale in the current study was .92 .

Patient Health Questionnaire-9 (PHQ-9) (Kroenke, Spitzer, \& Williams, 2001) is a 9-item self-report questionnaire that measures the degree of depression symptom severity. Items are scored on a 4-point scale with (0) indicating "does not exist," and (3) indicating "nearly every day." The scores range between 0 and 27, with a cut-off range of 15-19 indicating moderately severe depression and 20 and above indicating severe depression. The Arabic version of the PhQ-9 was previously validated in Arabic samples (Sawaya et al., 2016). Cronbach's alpha reliability for the instrument in the current study was .88 .

\section{Data Analysis}

We used Cohen's (1992) criteria and recommendations to confirm the sample size necessary to detect a medium population effect size at power $=.80$ for $\alpha=.05$ for the study's number of variables. The data were analyzed utilizing IBM-SPSS 22. There were no missing data reported. In addition to descriptives, we conducted a linear polynomial one-way ANOVA. We used the Tukey HSD Post hoc for multiple comparisons to test for differences between the Arab countries in cumulative traumas, trauma types, COVID-19 traumatic stress, PTSD, depression, and anxiety.

We conducted stepwise multiple regression analyses, for each Arab subsample, with PTSD, depression, and anxiety as dependent variables. The data were evaluated to ensure that the multivariate tests' assumptions were fulfilled (linearity, multicollinearity, homogeneity of variances, and homogeneity of covariance-variance matrices). The results of Bartlett's Test of Sphericity $(p<0.001)$ and the residual SSCP matrix shows that the variables under analysis met the assumptions of linearity and multicollinearity. Also, the results of Levene's test of equality of variances and Box's M test of equality of variancecovariance matrices indicated that homogeneity of variances and homogeneity of variance-covariance matrices were satisfied $(p>0.01)$. We tested for collinearity between variables, and variance inflation factor (VIF) was less than 5.00 for the model, indicating no multicollinearity (e.g., Hair, Hult, Ringle, \& Sarstedt, 2017; Williams, Grajales, \& Kurkiewicz, 2013). In the first step in each analysis, we recoded the categorical variables into dummy variables and entered gender, age, religion, education, and income as independent variables. 
In the second step, we entered "cumulative stressors and traumas" as an independent variable to control their potential impact. In the third step, we entered COVID-19 traumatic stress as an independent variable.

\section{Results}

\section{Descriptives}

Table 2 presents descriptive statistics for the overall sample and each country subsample. The mean occurrence score for cumulative stressors and trauma for the overall sample was 6.94, with SD of 5.62. For COVID-19 traumatic stress, the overall mean was 33.52 , with SD of 8.45 . For PTSD ( $M=$ $25.54, \mathrm{SD}=16.70), 36.6 \%$ of the complete sample scored at 31 or above (the cut-off score for probable PTSD diagnosis). For the generalized anxiety disorder scale $(\mathrm{M}=5.94, \mathrm{SD}=$ 5.19), $6.3 \%$ scored at 15 or above, which is the cut-off score of severe generalized anxiety disorder. For depression $(\mathrm{M}=$ 7.91, $\mathrm{SD}=6.06), 12.1 \%$ of the total sample scored at 15 , which is the cut-off score for moderate depression, while $4.9 \%$ scored at 20 , which is the cut-off score for severe depression. While Iraqis and Palestinians had the highest cumulative stressors and traumas load, Egyptians had the highest score on COVID19 traumatic stress and the highest probable PTSD (49\%) and depression.

\section{Analysis of Variance: ANOVA}

The differences between the countries (in linear terms) in CTS, COVID-19 traumatic stress, its three subscales, PTSD, anxiety, and depression, were all significant (see Table 3). Post hoc comparisons using the Tukey HSD test indicated that Egypt had significantly higher levels of overall COVID-19 traumatic stress than all the other Arab countries. Egypt also had significantly higher levels of the COVID-19 fears subscale for all other countries except for Algeria, the COVID19 economic trauma subscale (except for Jordan), and the COVID-19 disturbed routine and isolation subscale (except for Jordan and Palestine and Iraq). The Egyptian sample also had significantly higher levels of PTSD, anxiety, and depression. The Palestine and Iraq subsample was significantly higher in cumulative trauma load than the other Arab countries, but not higher in COVID-19 traumatic stress or PTSD. Table 1S in the supplemental material provides the statistical details of multiple comparisons. Figures 1, 2, 3, 4 and 5 present the difference in the means of COVID-19 traumatic stress, anxiety, depression, PTSD, and cumulative stressors and traumas in the different Arab subsamples. Figures 1S, 2S, and $3 \mathrm{~S}$ in the supplemental material provide the means of COVID-19 traumatic stress subscales (fears of infection and death, economic trauma, and disturbed routines/ isolation) in the different Arab subsamples.

\section{Stepwise Multiple Regression}

To measure the impact of COVID-19 on PTSD, anxiety, and depression (as dependent variables) in each country, after accounting for the variance explained by other stressors and traumas (other than COVID-19 traumatic stress), we used stepwise multiple regression. We entered gender, age, religion, education, and income in the first step. In the second step, we entered cumulative stressors and traumas, and in the

Table 2 Mean and standard deviation of PTSD, depression, anxiety, COVID-19 traumatic stress, and cumulative trauma load in each subsample

\begin{tabular}{|c|c|c|c|c|c|}
\hline Countries & PTSD & Depression & Anxiety & COVID-19 TS & CTS \\
\hline Egypt $(\mathrm{N}=255)$ & $\begin{array}{l}(M=33.15, S D=18.58) \\
49 \% \text { scored at } 31 \text { the cut-off } \\
\text { score for probable PTSD }\end{array}$ & $(\mathrm{M}=10.49, \mathrm{SD}=6.70)$ & $(\mathrm{M}=8.18, \mathrm{SD}=6.01)$ & $(\mathrm{M}=37.68, \mathrm{SD}=9.20)$ & $(\mathrm{M}=6.90, \mathrm{SD}=5.29)$ \\
\hline Kuwait N = 442) & $\begin{array}{l}(\mathrm{M}=24.18, \mathrm{SD}=15.30), 33 \% \\
\text { scored at } 31 \text { the cut-off score } \\
\text { for probable PTSD }\end{array}$ & $(\mathrm{M}=7.50, \mathrm{SD}=5.55)$ & $(\mathrm{M}=5.33, \mathrm{SD}=4.83)$ & $(\mathrm{M}=32.19, \mathrm{SD}=7.40)$ & $(\mathrm{M}=6.73, \mathrm{SD}=6.79)$ \\
\hline Jordan $(\mathrm{N}=216)$ & $\begin{array}{l}(\mathrm{M}=25.25, \mathrm{SD}=16.47), 33.3 \% \\
\text { scored at } 31 \text { the cut-off score } \\
\text { for probable PTSD }\end{array}$ & $(\mathrm{M}=8.46, \mathrm{SD}=6.14)$ & $(\mathrm{M}=6.54, \mathrm{SD}=5.04)$ & $(\mathrm{M}=34.98, \mathrm{SD}=8.57)$ & $(\mathrm{M}=5.51, \mathrm{SD}=4.30)$ \\
\hline Algeria $(\mathrm{N}=110)$ & $\begin{array}{l}(\mathrm{M}=21.15, \mathrm{SD}=15.57), 22 \% \\
\text { scored at } 31 \text { the cut-off score } \\
\text { for probable PTSD }\end{array}$ & $(\mathrm{M}=6.70, \mathrm{SD}=5.48)$ & $(\mathrm{M}=4.75, \mathrm{SD}=4.72)$ & $(\mathrm{M}=32.38, \mathrm{SD}=7.52)$ & $(\mathrm{M}=7.60, \mathrm{SD}=4.30)$ \\
\hline $\begin{array}{l}\text { Iraq and Palestine } \\
\quad(N=139)\end{array}$ & $\begin{array}{l}(\mathrm{M}=26.44, \mathrm{SD}=16.24), 36 \% \\
\text { scored at } 31 \text { the cut-off score } \\
\text { for probable PTSD }\end{array}$ & $(\mathrm{M}=6.99, \mathrm{SD}=5.08)$ & $(\mathrm{M}=5.78, \mathrm{SD}=4.86)$ & $(\mathrm{M}=33.89, \mathrm{SD}=9.03)$ & $(\mathrm{M}=10.05, \mathrm{SD}=5.44)$ \\
\hline $\begin{array}{l}\text { Saudi Arabia } \\
\qquad(\mathrm{N}=212)\end{array}$ & $\begin{array}{l}(\mathrm{M}=21.23, \mathrm{SD}=15.27), 20.3 \% \\
\text { scored at } 31 \text { the cut-off score } \\
\text { for probable PTSD }\end{array}$ & $(\mathrm{M}=15.27, \mathrm{SD}=21.23)$ & $(\mathrm{M}=6.32, \mathrm{SD}=5.47)$ & $(\mathrm{M}=4.60, \mathrm{SD}=4.53)$ & $(\mathrm{M}=6.48, \mathrm{SD}=4.34)$ \\
\hline
\end{tabular}

CTS, Cumulative Stressors and Traumas; COVID-19 TS, COVID-19 traumatic Stress 
Table 3 ANOVA for the significance of differences in the effects of main variables between and within groups

\begin{tabular}{|c|c|c|c|c|c|}
\hline Variables & Sum of squares & df & Mean square & $\mathrm{F}$ & Sig. \\
\hline \multicolumn{6}{|c|}{ 1.COVID-19 Traumatic Stress } \\
\hline Between groups & 8243.96 & 5 & 1648.79 & \multirow[t]{3}{*}{25.14} & \multirow[t]{3}{*}{.000} \\
\hline Within Groups & $89,713.01$ & 1368 & 65.58 & & \\
\hline Total & $97,956.969$ & 1373 & & & \\
\hline \multicolumn{6}{|c|}{ 2. COVID-19 fears of future infection } \\
\hline Between groups & 1725.77 & 5 & 345.15 & \multirow[t]{3}{*}{15.18} & \multirow[t]{3}{*}{.000} \\
\hline Within Groups & $31,102.92$ & 1368 & 22.74 & & \\
\hline Total & $32,828.69$ & 1373 & & & \\
\hline \multicolumn{6}{|c|}{ 3. COVID-19 economic trauma } \\
\hline Between groups & 2596.09 & 5 & 519.22 & \multirow[t]{3}{*}{44.76} & \multirow[t]{3}{*}{.000} \\
\hline Within Groups & $15,870.74$ & 1368 & 11.601 & & \\
\hline Total & $18,466.83$ & 1373 & & & \\
\hline \multicolumn{6}{|c|}{ 4. COVID-19 impact of routine disturbance and isolation } \\
\hline Between groups & 228.51 & 5 & 45.70 & \multirow[t]{3}{*}{6.74} & \multirow[t]{3}{*}{.000} \\
\hline Within Groups & 9274.33 & 1368 & 6.78 & & \\
\hline Total & 9502.84 & 1373 & & & \\
\hline \multicolumn{6}{|c|}{ 5. Cumulative Stressors and Trauma Occurrences } \\
\hline Between groups & 1903.422 & 5 & 380.684 & \multirow[t]{3}{*}{12.554} & \multirow[t]{3}{*}{.000} \\
\hline Within Groups & $41,482.069$ & 1368 & 30.323 & & \\
\hline Total & $43,385.491$ & 1373 & & & \\
\hline \multicolumn{6}{|l|}{ 6.PTSD } \\
\hline Between groups & $21,766.17$ & 5 & 4353.23 & \multirow[t]{3}{*}{16.49} & \multirow[t]{3}{*}{.000} \\
\hline Within Groups & $361,206.80$ & 1368 & 264.040 & & \\
\hline Total & $382,972.97$ & 1373 & & & \\
\hline \multicolumn{6}{|l|}{ 7.Anxiety } \\
\hline Between groups & 2058.25 & 5 & 411.65 & \multirow[t]{3}{*}{16.12} & \multirow[t]{3}{*}{.000} \\
\hline Within Groups & $34,941.85$ & 1368 & 25.54 & & \\
\hline Total & $37,000.11$ & 1373 & & & \\
\hline \multicolumn{6}{|l|}{ 8. Depression } \\
\hline Between groups & 2640.647 & 5 & 528.13 & \multirow[t]{3}{*}{15.12} & \multirow[t]{3}{*}{.000} \\
\hline Within Groups & $47,784.52$ & 1368 & 34.93 & & \\
\hline Total & $50,425.17$ & 1373 & & & \\
\hline
\end{tabular}

third and last step, we entered COVID-19 traumatic stress. The results indicated significant main effects for previous cumulative stressors and traumas on PTSD, depression, and anxiety across all countries. Betas for these effects ranged between .48 and .24 for depression, between .45 and .22 for anxiety, and between .39 and .22 for PTSD. In analyses for each country, COVID-19 stress accounted for unique significant variance above and beyond the variance accounted for by cumulative stressors and traumas for anxiety in all country subsamples. Betas for COVID-10 traumatic stress predicting anxiety ranged from .19 to .32 . COVID-19 traumatic stress also accounted for unique significant variance above and beyond the variance accounted for by cumulative stressors and traumas for PTSD in all country samples, except for Algeria (see Table 4). Betas for COVID-10 traumatic stress predicting
PTSD ranged from .06 to .26. Similarly, COVID-19 traumatic stress accounted for unique variance in predicting depression in all country samples except for Algeria, with Betas ranging from .12 to .19 (see Tables $2 \mathrm{~S}$ and $3 \mathrm{~S}$ for results of all of these analyses). Note that, in all the analyses, variance inflation factor (VIF) values indicated no collinearity present in the data (see, for example, Table 4).

\section{Discussion}

The results of this study suggest that COVID-19 traumatic stress uniquely contributes to increased mental distress (e.g., depression, anxiety, PTSD symptoms), over and above the experience of previous trauma, in most Arab countries. Of 
Fig. 1 The mean of COVID-19 traumatic stress in different Arab subsamples

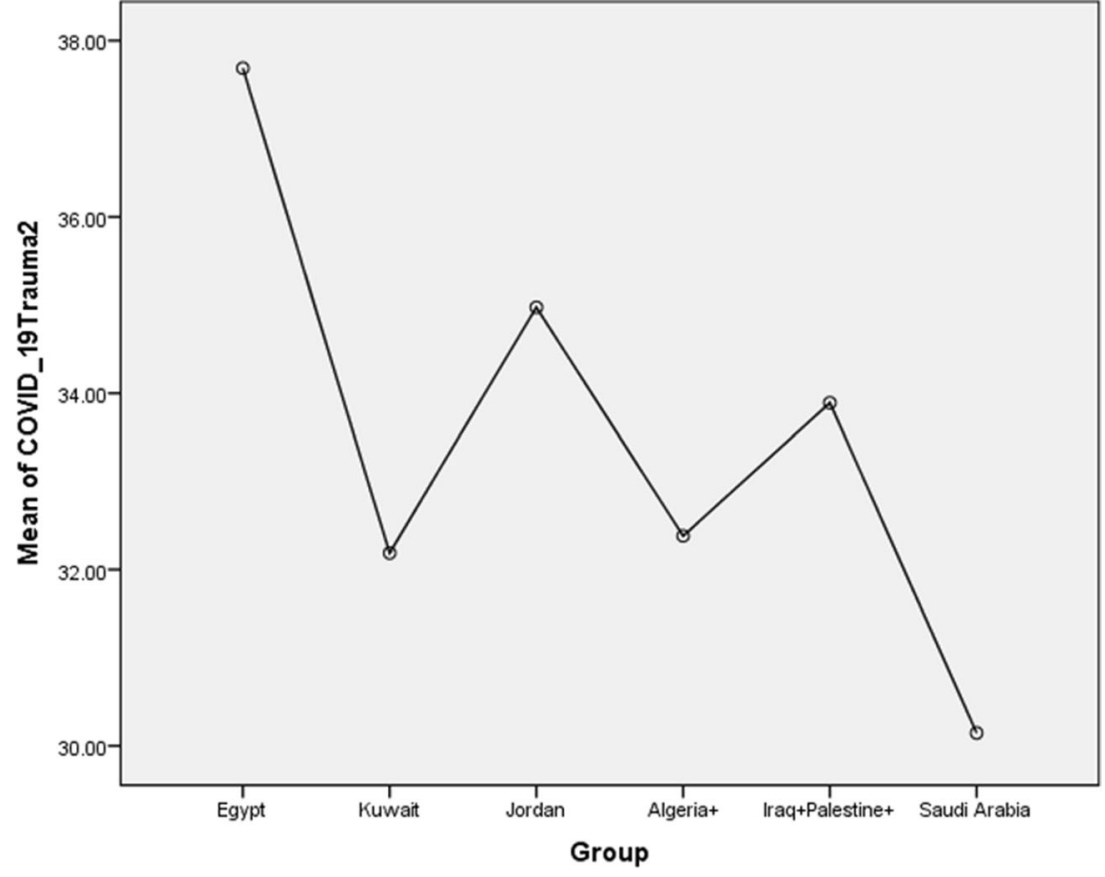

particular note is that, while Palestinians and Iraqis had the highest trauma load in the Arab samples due to previous cumulative stressors and traumas, they did not have the highest load of PTSD, depression, or anxiety. The Egyptians sample had the highest PTSD, depression, and anxiety rates, and the highest rates of COVID-19 traumatic stress, suggesting a relationship between these variables.

This study also suggests that the effects of COVID-19 related traumatic stress differ across Arab countries according to population density and economy. For instance, more densely populated countries like Egypt that have a more significant potential for spreading the virus had greater mental health impact than the countries with lower population density like Algeria and Saudi Arabia. While El-Zoghby et al. (2020), as mentioned in the introduction, found that $41.4 \%$ of their Egyptian sample scored on the high end of a measure for PTSD, the results of our study also found that Egyptians had a higher probability of PTSD (49\%) (which may be comparable to El-Zoghby et al., 2020, earlier findings) and the highest scores on COVID19 traumatic stress. These PTSD ratings are
Fig. 2 The mean of anxiety in different Arab subsamples

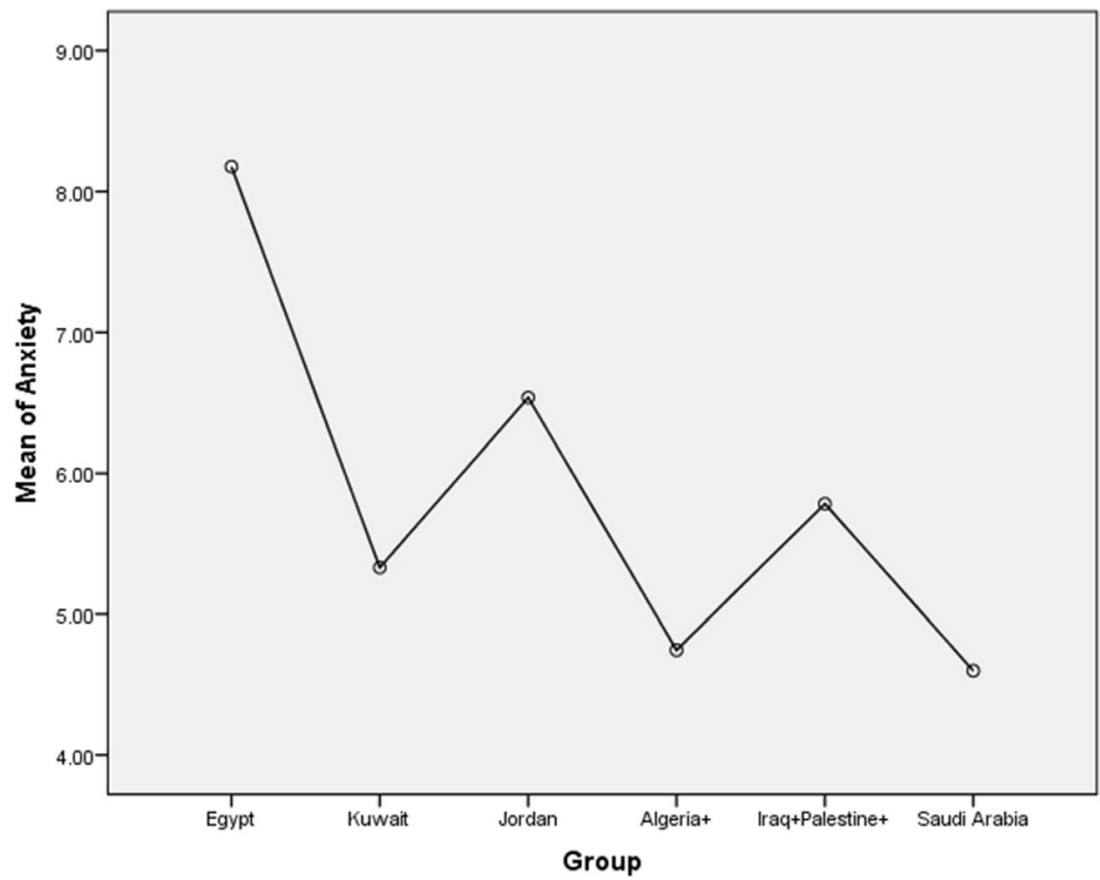


Fig. 3 The mean of depression in different Arab subsamples

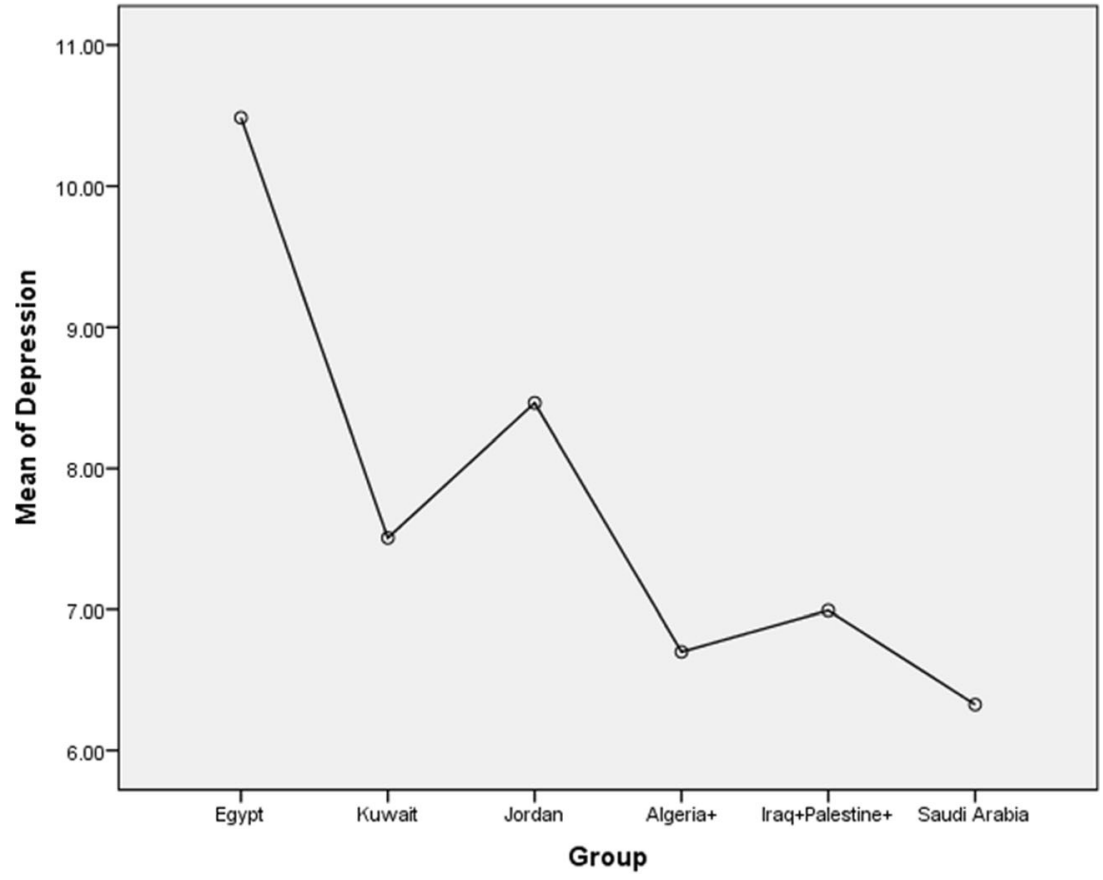

higher than in previous studies where, three years ago and before the pandemic, researchers found that $32.2 \%$ of the participants in a comparable Egyptian sample met the criteria for PTSD (Kira, Shuwiekh, Rice, \& Ashby, 2018b). This study's results indicated the unique contribution of COVID-19 traumatic stress in predicting PTSD suggests that these increases may be attributed to the additive impact of COVID-19.

The results of the stepwise multiple regression suggest several demographic factors are related to mental health outcomes. For instance, older age was consistently predictive of less PTSD, depression, and anxiety in most countries in this COVID-19 context. In a recent study, Palgi et al. (2020) found similar results. The authors that, while old age increased the risk of the negative physical impact of COVID-19, age was unrelated to depression or anxiety. Specifically, they found that adults above 60 who are at higher risk for COVID-19 complications displayed greater resilience to psychiatric disorders associated with the COVID-19 crisis. This finding may
Fig. 4 The mean of PTSD in different Arab subsamples

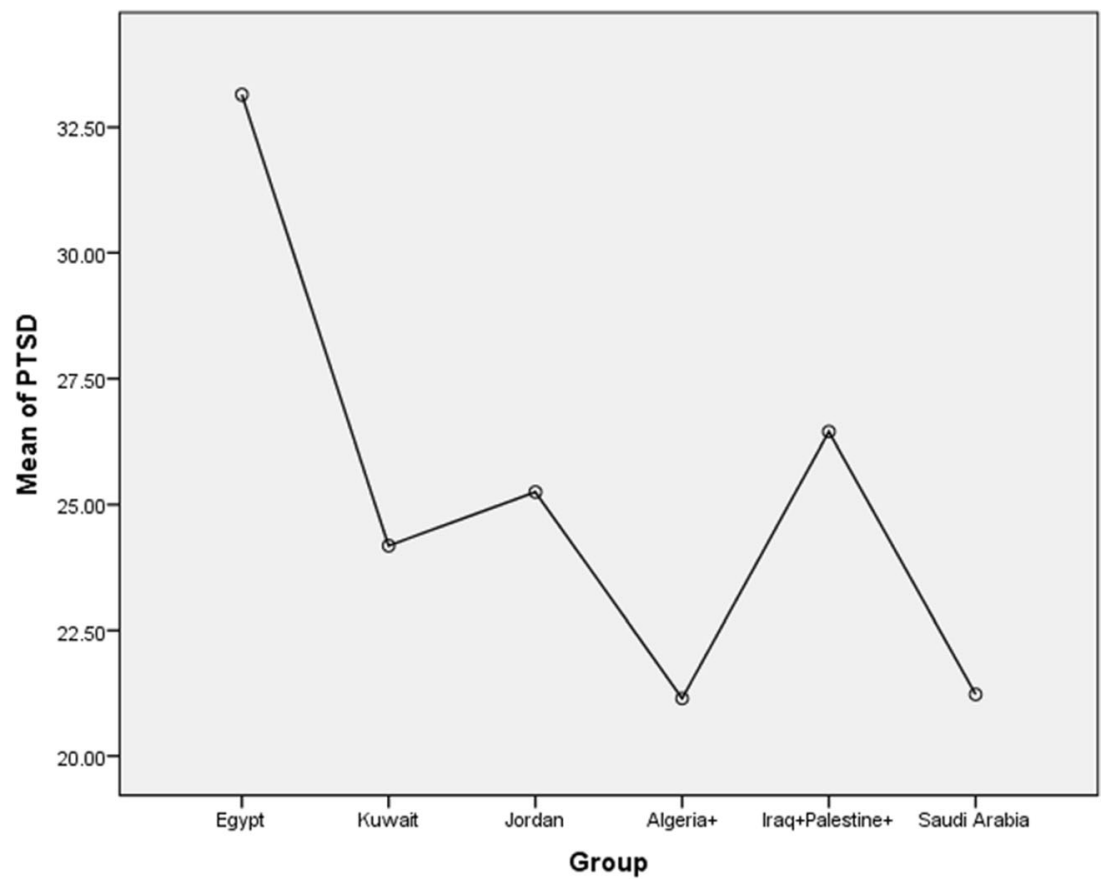


Fig. 5 The mean of cumulative stressors and traumas in different Arab subsamples

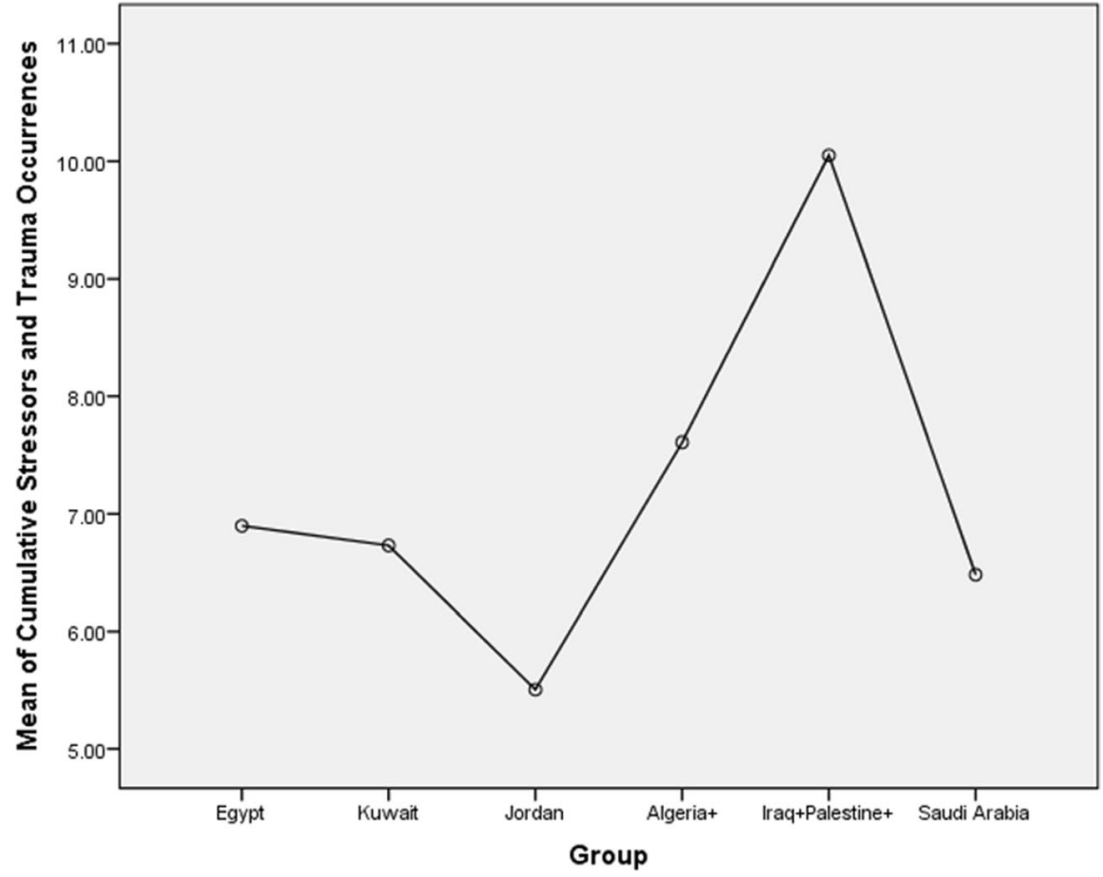

be because the elderly are more aware of the risks associated with COVID-19 and, consequently, more disciplined and less impulsive in taking preventive measures.

While education was not a significant predictor of distress in this study, income was a significant predictor of lower PTSD, anxiety, and depression in the relatively higherincome countries of Kuwait, Jordan, Saudi Arabia, but not in Egypt, Algeria, Iraq, or Palestine. This finding suggests that the economic impact of COVID-19, which is one of the critical stressors of COVID-19 (e.g., McKibbin \& Fernando, 2020), may be lessened for individuals with higher incomes. This case might be especially evident in Arab countries with higher average incomes like Kuwait and Saudi Arabia.

Religion (e.g., being Christian) was also a significant factor in predicting mental health outcomes in this study, but only in the Egyptian sample. In this study, identifying as Christian was predictive of increased PTSD, depression, and anxiety in the Egyptian subsample. The Egyptian subsample had a relatively sizeable Christian minority (20.4\%) compared to other country samples (9\% in Jordan, Algeria, and Iraq/Palestine, respectively). In this study, Christian minority participants in Egypt had higher PTSD, anxiety, and depression scores than participants in the Muslim majority. Increased mental health among a Christian minority in Arabic countries is consistent with social identity and minority stress theories (e.g., Kira et al., 2019c) and a recent study on Egypt's Christian minority (Kira \& Shuwiekh, in press), suggesting that this additional stress significantly undermines well-being.

The current study has several conceptual and clinical implications. Conceptually, the study highlights the multiple dimensions of COVID-19 (Fears, economic, and isolation) and their unique and pervasive mental health impact. The study results also suggest the need for additional studies to determine whether the combination of symptoms related to COVID-19 traumatic stress (i.e., PTSD, anxiety, depression) can be best understood using existing comorbidity frameworks within a new unique diagnostic category such as post-COVID-19 traumatic stress disorder. Clinically, the current study indicates a clear need for mental health intervention for Arab countries, especially those most affected. The results suggest high levels of distress that would warrant the attention and assistance of world health organizations. National centers, universities, and mental health services in these countries might also be mobilized to provide effective prevention and intervention strategies. Telehealth and online interventions and utilizing social media also can be useful as proven to be effective options (e.g., Zhou et al., 2020a, b).

The current study has several limitations. One of the limitations is that we conducted the study in a convenient sample that is relatively skewed towards younger ages and females with limited and biased representation. We recommend more studies that use more representative and balanced samples and in more Arab countries. Further, the measures we used depended on participants' self-reports, which could be subject to under- or over-reporting of events due to current symptoms, embarrassment, or social desirability. Also, the study utilized a cross-sectional design. Future studies may use longitudinal studies if feasible. Despite these limitations, the current study results highlighted the differential negative impact of COVID19 on different Arab countries. Further, this study offers evidence of the impact of COVID-19 traumatic stress in predicting mental health outcomes in several Arab countries and has significant conceptual and clinical implications. 
Table 4 Stepwise multiple regression for the effects of COVID-19 traumatic stress on PTSD after entering cumulative stressors and traumas on the Arab sub-samples

The Effects of COVID-19 traumatic stress on PTSD after controlling for previous cumulative stressors and traumas occurrences (Total variance accounted for the model $\mathrm{R}^{2}=.251$ ) in Egypt

\begin{tabular}{|c|c|c|c|c|c|c|c|c|}
\hline & $B$ & $S E$ & Beta & $t$ & Sig. & $V I F$ & $R^{2}$ (change in $\left.R^{2}\right)$ & $F$ for change in $R^{2}$ \\
\hline Model 1: Step One & & & & & & & .057 & $3.017(.012)$ \\
\hline Gender & -1.923 & 2.926 & -.042 & -.657 & .512 & 1.097 & & \\
\hline Age & -.522 & .184 & -.190 & -2.830 & .005 & 1.193 & & \\
\hline religion & 9.506 & 2.942 & .207 & 3.231 & .001 & 1.079 & & \\
\hline education & 1.193 & 2.233 & .034 & .534 & .594 & 1.057 & & \\
\hline income & .498 & 3.019 & .010 & .165 & .869 & 1.015 & & \\
\hline Model 2: Step Two & & & & & & & .144 & $44.634(<.001)$ \\
\hline Gender & .443 & 2.722 & .010 & .163 & .871 & 1.116 & & \\
\hline Age & -.581 & .170 & -.212 & -3.408 & .001 & 1.196 & & \\
\hline religion & 8.252 & 2.720 & .179 & 3.034 & .003 & 1.084 & & \\
\hline education & 1.135 & 2.060 & .032 & .551 & .582 & 1.057 & & \\
\hline income & .767 & 2.785 & .016 & .276 & .783 & 1.015 & & \\
\hline Cumulative Stressors and Traumas & 1.354 & .203 & .386 & 6.681 & .000 & 1.035 & & \\
\hline Model 3: Step Three & & & & & & & .050 & $16.647(<.001)$ \\
\hline Gender & -2.410 & 2.731 & -.053 & -.883 & .378 & 1.195 & & \\
\hline Age & -.634 & .166 & -.231 & -3.822 & .000 & 1.203 & & \\
\hline religion & 8.102 & 2.638 & .176 & 3.071 & .002 & 1.085 & & \\
\hline education & 1.005 & 1.998 & .028 & .503 & .615 & 1.057 & & \\
\hline income & 2.420 & 2.731 & .050 & .886 & .376 & 1.038 & & \\
\hline Cumulative Stressors and Traumas & 1.260 & .198 & .36 & 6.366 & .000 & 1.050 & & \\
\hline COVID-19 Traumatic Stress & .475 & .116 & .24 & 4.080 & .000 & 1.095 & & \\
\hline
\end{tabular}

The Effects of COVID-19 traumatic stress on PTSD after controlling for previous cumulative stressors and traumas occurrences (Total variance accounted for the model $\mathrm{R}^{2}=.236$ ) in Kuwait

\begin{tabular}{|c|c|c|c|c|c|c|c|c|}
\hline & $B$ & $S E$ & Beta & $t$ & Sig. & $V I F$ & $R^{2}$ (change in $\left.R^{2}\right)$ & $F$ for change in $R^{2}$ \\
\hline Model 1: Step One & & & & & & & \multirow[t]{6}{*}{.034} & \multirow[t]{6}{*}{$3.040(.010)$} \\
\hline Gender & 3.020 & 2.687 & .060 & 1.124 & .262 & 1.301 & & \\
\hline Age & -.040 & .076 & -.030 & -.528 & .598 & 1.418 & & \\
\hline religion & -.546 & 11.226 & -.002 & -.049 & .961 & 1.097 & & \\
\hline education & .299 & 1.490 & .010 & .200 & .841 & 1.074 & & \\
\hline income & -6.039 & 1.732 & -.165 & -3.487 & .001 & 1.006 & & \\
\hline Model 2: Step Two & & & & & & & \multirow[t]{7}{*}{.138} & \multirow[t]{7}{*}{$72.664(<.001)$} \\
\hline Gender & 2.633 & 2.491 & .053 & 1.057 & .291 & 1.302 & & \\
\hline Age & -.112 & .071 & -.083 & -1.581 & .115 & 1.439 & & \\
\hline religion & 5.291 & 10.426 & .023 & .507 & .612 & 1.102 & & \\
\hline education & -.097 & 1.381 & -.003 & -.070 & .944 & 1.075 & & \\
\hline income & -4.458 & 1.616 & -.122 & -2.760 & .006 & 1.020 & & \\
\hline Cumulative Stressors and Traumas & .852 & .100 & .378 & 8.524 & .000 & 1.034 & & \\
\hline Model 3: Step Three & & & & & & & \multirow[t]{8}{*}{.064} & \multirow[t]{8}{*}{$36.111(<.001)$} \\
\hline Gender & 2.618 & 2.396 & .052 & 1.093 & .275 & 1.302 & & \\
\hline Age & -.104 & .068 & -.077 & -1.521 & .129 & 1.439 & & \\
\hline religion & 4.165 & 10.031 & .018 & .415 & .678 & 1.102 & & \\
\hline education & .347 & 1.331 & .011 & .261 & .794 & 1.078 & & \\
\hline income & -3.272 & 1.567 & -.089 & -2.089 & .037 & 1.036 & & \\
\hline Cumulative Stressors and Traumas & .751 & .098 & .333 & 7.695 & .000 & 1.065 & & \\
\hline COVID-19 Traumatic Stress & .535 & .089 & .259 & 6.009 & .000 & 1.054 & & \\
\hline
\end{tabular}

The Effects of COVID-19 traumatic stress on PTSD after controlling for previous cumulative stressors and traumas occurrences (Total variance accounted for the model $\mathrm{R}^{2}=.252$ ) in Jordan

$$
\text { B SE Beta } \quad t \quad \text { Sig. VIF } \quad R^{2} \text { (change in } R^{2} \text { ) } \quad \text { F for change in } R^{2}
$$


Table 4 (continued)

\begin{tabular}{|c|c|c|c|c|c|c|c|c|}
\hline Model 1: Step One & & & & & & & .102 & $4.770(<.001)$ \\
\hline Gender & 9.196 & 3.456 & .179 & 2.661 & .008 & 1.059 & & \\
\hline Age & -.101 & .111 & -.066 & -.909 & .364 & 1.216 & & \\
\hline religion & 3.279 & 3.967 & .058 & .827 & .409 & 1.145 & & \\
\hline education & -.208 & 2.051 & -.007 & -.101 & .919 & 1.006 & & \\
\hline income & -9.519 & 2.788 & -.226 & -3.414 & .001 & 1.023 & & \\
\hline Model 2: Step Two & & & & & & & .118 & $31.721(<.001)$ \\
\hline Gender & 8.151 & 3.233 & .159 & 2.521 & .012 & 1.062 & & \\
\hline Age & -.228 & .107 & -.147 & -2.140 & .034 & 1.273 & & \\
\hline religion & 4.578 & 3.712 & .081 & 1.233 & .219 & 1.150 & & \\
\hline education & -.581 & 1.917 & -.019 & -.303 & .762 & 1.007 & & \\
\hline income & -7.998 & 2.618 & -.190 & -3.055 & .003 & 1.034 & & \\
\hline Cumulative Stressors and Traumas & 1.353 & .240 & .353 & 5.632 & .000 & 1.055 & & \\
\hline Model 3: Step Three & & & & & & & .032 & $8.778(.003)$ \\
\hline Gender & 7.802 & 3.177 & .152 & 2.456 & .015 & 1.064 & & \\
\hline Age & -.218 & .105 & -.141 & -2.079 & .039 & 1.274 & & \\
\hline religion & 4.184 & 3.647 & .074 & 1.147 & .253 & 1.151 & & \\
\hline education & -.310 & 1.884 & -.010 & -.165 & .869 & 1.009 & & \\
\hline income & -5.932 & 2.664 & -.141 & -2.227 & .027 & 1.110 & & \\
\hline Cumulative Stressors and Traumas & 1.261 & .238 & .329 & 5.301 & .000 & 1.073 & & \\
\hline COVID-19 Traumatic Stress & .359 & .121 & .187 & 2.963 & .003 & 1.107 & & \\
\hline
\end{tabular}

The Effects of COVID-19 traumatic stress on PTSD after controlling for previous cumulative stressors and traumas occurrences (Total variance accounted for the model $\mathrm{R}^{2}=.176$ ) in Algeria

$\begin{array}{lllllll}\text { Model 1: Step One } & B & S E & \text { Beta } & t & \text { Sig. } & \text { VIF } \\ \text { Gender } & & & & & & \\ \text { Age } & -.643 & 4.107 & -.016 & -.156 & .876 & 1.096 \\ \text { religion } & .051 & .127 & .040 & .397 & .692 & 1.134 \\ \text { education } & -9.344 & 16.002 & -.057 & -.584 & .561 & 1.049 \\ \text { income } & -4.474 & 2.644 & -.164 & -1.692 & .094 & 1.031 \\ \text { Model 2: Step Two } & -5.850 & 3.856 & -.150 & -1.517 & .132 & 1.071 \\ \text { Gender } & & & & & & \\ \text { Age } & -2.091 & 3.865 & -.051 & -.541 & .590 & 1.205 \\ \text { religion } & -.067 & .123 & -.054 & -.547 & .586 & 1.078 \\ \text { education } & -19.16 & 15.194 & -.117 & -1.261 & .210 & 1.052 \\ \text { income } & -3.089 & 2.501 & -.113 & -1.235 & .220 & 1.095 \\ \text { Cumulative Stressors and Traumas } & -3.717 & 3.652 & -.095 & -1.018 & .311 & 1.134 \\ \text { Model 3: Step Three } & 1.362 & .345 & .376 & 3.942 & .000 & 1.205 \\ \text { Gender } & & & & & & \\ \text { Age } & -2.016 & 3.878 & -.049 & -.520 & .604 & 1.080 \\ \text { religion } & -.070 & .123 & -.056 & -.571 & .570 & 1.059 \\ \text { education } & -19.61 & 15.254 & -.120 & -1.286 & .201 & 1.120 \\ \text { income } & -2.960 & 2.517 & -.109 & -1.176 & .242 & 1.191 \\ \text { Cumulative Stressors and Traumas } & -3.369 & 3.704 & -.087 & -.910 & .365 & 1.112 \\ \text { COVID-19 Traumatic Stress } & 1.313 & .355 & .363 & 3.696 & .000 & 1.080 \\ & .124 & .196 & .060 & .634 & .528 & 1.059\end{array}$

$R^{2}$ (change in $\left.R^{2}\right) \quad F$ for change in $R^{2}$ $.048 \quad 1.049(.393)$

.125

$15.542(<.001)$

.003

$.402(.528)$

The Effects of COVID-19 traumatic stress on PTSD after controlling for previous cumulative stressors and traumas occurrences (Total variance accounted for the model $\mathrm{R}^{2}=.240$ ) in Iraq and Palestine

Model 1: Step One

Gender

Age

religion

education

income

Model 2: Step Two

Gender

Age

religion

education

income

Cumulative Stressors and Traumas

Model 3: Step Three

Gender

$B \quad S E$

Age

$\begin{array}{llllll}B & S E & \text { Beta } & t & \text { Sig. } & \text { VIF } \\ 6.606 & 2.723 & .203 & 2.426 & .017 & 1.062 \\ -.206 & .104 & -.166 & -1.985 & .049 & 1.064 \\ 4.696 & 4.801 & .082 & .978 & .330 & 1.054 \\ .301 & 1.952 & .013 & .154 & .878 & 1.022 \\ -8.560 & 3.658 & -.195 & -2.340 & .021 & 1.057 \\ & & & & & \\ 6.314 & 2.585 & .194 & 2.443 & .016 & 1.062 \\ -.268 & .100 & -.217 & -2.691 & .008 & 1.064 \\ 6.170 & 4.570 & .107 & 1.350 & .179 & 1.054 \\ -.293 & 1.858 & -.012 & -.158 & .875 & 1.022 \\ -5.519 & 3.554 & -.126 & -1.553 & .123 & 1.057 \\ .955 & .241 & .320 & 3.969 & .000 & 1.062 \\ & & & & & \\ 5.885 & 2.564 & .181 & 2.295 & .023 & 1.071 \\ -.261 & .099 & -.211 & -2.650 & .009 & 1.092\end{array}$

$R^{2}$ (change in $\left.R^{2}\right) \quad F$ for change in $R^{2}$ .123 3.746 (.003)

.93

$15.752(<.001)$

.023

$4.018(.047)$ 
Table 4 (continued)

\begin{tabular}{|c|c|c|c|c|c|c|c|c|}
\hline religion & 5.642 & 4.527 & .098 & 1.246 & .215 & 1.065 & & \\
\hline education & -.567 & 1.843 & -.024 & -.308 & .759 & 1.035 & & \\
\hline income & -4.445 & 3.554 & -.101 & -1.251 & .213 & 1.134 & & \\
\hline Cumulative Stressors and Traumas & .815 & .248 & .273 & 3.286 & .001 & 1.071 & & \\
\hline COVID-19 Traumatic Stress & .295 & .147 & .164 & 2.005 & .047 & 1.092 & & \\
\hline \multicolumn{9}{|c|}{$\begin{array}{l}\text { The Effects of COVID-19 traumatic stress on PTSD after controlling for previous cumulative stressors and traumas occurrences (Total variance } \\
\text { accounted for the model } \mathrm{R}^{2}=.294 \text { ) in Saudi Arabia }\end{array}$} \\
\hline & $B$ & $S E$ & Beta & $t$ & Sig. & $V I F$ & $R^{2}$ (change in $R^{2}$ ) & $F$ for change in $R^{2}$ \\
\hline Model 1: Step One & & & & & & & .119 & $5.553(<.001)$ \\
\hline Gender & -.883 & 2.576 & -.023 & -.343 & .732 & 1.043 & & \\
\hline Age & -.402 & .091 & -.294 & -4.413 & .000 & 1.040 & & \\
\hline religion & -.975 & 14.558 & -.004 & -.067 & .947 & 1.002 & & \\
\hline education & .113 & 1.613 & .005 & .070 & .944 & 1.018 & & \\
\hline income & -6.225 & 2.233 & -.182 & -2.787 & .006 & 1.002 & & \\
\hline Model 2: Step Two & & & & & & & .154 & $43.578(<.001)$ \\
\hline Gender & 1.367 & 2.370 & .035 & .577 & .565 & 1.065 & & \\
\hline Age & -.302 & .084 & -.221 & -3.585 & .000 & 1.075 & & \\
\hline religion & -6.158 & 13.276 & -.028 & -.464 & .643 & 1.005 & & \\
\hline education & .032 & 1.468 & .001 & .022 & .982 & 1.019 & & \\
\hline income & -3.721 & 2.068 & -.109 & -1.799 & .073 & 1.037 & & \\
\hline Cumulative Stressors and Traumas & 1.442 & .218 & .410 & 6.601 & .000 & 1.088 & & \\
\hline Model 3: Step Three & & & & & & & .021 & $6.118(.014)$ \\
\hline Gender & 1.875 & 2.350 & .049 & .798 & .426 & 1.073 & & \\
\hline Age & -.277 & .084 & -.203 & -3.304 & .001 & 1.091 & & \\
\hline religion & -7.061 & 13.118 & -.032 & -.538 & .591 & 1.006 & & \\
\hline education & .271 & 1.453 & .011 & .186 & .852 & 1.023 & & \\
\hline income & -3.488 & 2.045 & -.102 & -1.705 & .090 & 1.039 & & \\
\hline Cumulative Stressors and Traumas & 1.330 & .220 & .378 & 6.037 & .000 & 1.135 & & \\
\hline COVID-19 Traumatic Stress & .324 & .131 & .152 & 2.473 & .014 & 1.096 & & \\
\hline
\end{tabular}

Acknowledgments The authors are grateful to Dr.Gada Ouda Hijazi, the researcher at the Palestinian Planning Center, and to Jumana Daibes a faculty of Allied Medical Science, in the Arab American University, Palestine, West Bank who helped to collect data from the West Bank of Palestine.

\section{Compliance with Ethical Standards}

Ethical Approval All procedures performed in studies involving human participants were in accordance with the ethical standards of the institutional and/or national research committee and with the 1964 Helsinki declaration and its later amendments or comparable ethical standards.

Informed Consent Informed consent was obtained from all individual participants included in the study.

Conflict of Interest All authors did not receive any grants for this work or honorariums related to this work and declare no conflict of interest.

\section{References}

Barr, J., \& Tassier, T. (2020). Are crowded cities the reason for the Covid-19 pandemic. Scientific American 17th of April.

Bedoya, E. Y., Ruíz, S., Córdoba, A., Rendón, G. D., Ruíz, G. I., \& Gómez, G. D. (2020). Traumatic events and psychopathological symptoms in university students. Revista de Psicopatología y Psicología Clínica, 1(1), 69-79.

Blevins, C. A., Weathers, F. W., Davis, M. T., Witte, T. K., \& Domino, J. L. (2015). The posttraumatic stress disorder checklist for DSM-5
(PCL-5): Development and initial psychometric evaluation. Journal of Traumatic Stress, 28, 489-498.

Brooks, S. K., Webster, R. K., Smith, L. E., Woodland, L., Wessely, S., Greenberg, N., \& Rubin, G. J. (2020). The psychological effects of quarantine and how to reduce it: Rapid review of the evidence. The Lancet., 395, 912-920. https://doi.org/10.1016/S0140-6736(20) 30460-8.

Cohen, J. (1992). A power primer. Psychological Bulletin, 112(1), 155159.

Dabashi, H. (2012). The Arab spring: The end of postcolonialism. Zed Books Ltd..

Dowd, J. B., Andriano, L., Brazel, D. M., Rotondi, V., Block, P., Ding, X., Liu, Y., \& Mills, M. C. (2020). Demographic science aids in understanding the spread and fatality rates of COVID-19. Proceedings of the National Academy of Sciences, 117(18), 96969698.

Eagle, G., \& Kaminer, D. (2013). Continuous traumatic stress: Expanding the lexicon of traumatic stress. Peace and Conflict: Journal of Peace Psychology, 19(2), 85-99.

Eltan, S. (2019). Psychometric properties of the cumulative trauma scale: Evaluation of the reliability and validity in a Turkish sample. A thesis submitted to graduate school of social science: Middle East Technical University, Turkey.

Goral, A., Lahad, M., \& Aharonson-Daniel, L. (2017). Differences in posttraumatic stress characteristics by duration of exposure to trauma. Psychiatry Research, 258, 101-107.

Hair, J. F., Hult, G. T. M., Ringle, C. M., \& Sarstedt, M. (2017). A primer on partial least squares structural equation modeling (PLS-SEM) (2nd ed.). Thousand Oaks, CA: Sage.

Head, D., Singh, T., \& Bugg, J. M. (2012). The moderating role of exercise on stress-related effects on the hippocampus and memory in later adulthood. Neuropsychology, 26(2), 133-143. 
Heidenrich, J. G. (1993). The Gulf war: How many Iraqis died? Foreign Policy, 90, 108-125.

Ibrahim, H., Ertl, V., Catani, C., Ismail, A. A., \& Neuner, F. (2018). The validity of posttraumatic stress disorder checklist for DSM-5 (PCL5 ) as screening instrument with Kurdish and Arab displaced populations living in the Kurdistan region of Iraq. BMC Psychiatry, $18(1), 259$

Kang, D., Choi, H., Kim, J. H., \& Choi, J. (2020). Spatial epidemic dynamics of the COVID-19 outbreak in China. International Journal of Infectious Diseases., 94, 96-102.

Kira, I., Ashby, J. S., Lewandowski, L., Alawneh, A. N., Mohanesh, J., \& Odenat, L. (2013a). Advances in continuous traumatic stress theory: Traumatogenic dynamics and consequences of intergroup conflict: The Palestinian adolescents case. Psychology, 4, 396-409.

Kira, I., Barger, B., Shuwiekh, H., Kucharska, J., \& Al-Huwailah, A. (2020a). The threshold non-linear model for the effects of cumulative stressors and traumas: A chained cusp catastrophe analysis. Psychology, 11, 385-403.

Kira, I., Barger, B., Shuwiekh, H., Kucharska, J., \& Al-Huwailah, A. H. (2019a). Cumulative stressors and traumas and suicide: A non-linear cusp dynamic systems model. Psychology, 10, 1999-2018.

Kira, I., Fawzi, M., \& Fawzi, M. (2013b). The dynamics of cumulative trauma and trauma types in adult patients with psychiatric disorders: Two cross-cultural studies. Traumatology: An International Journal, 19, 179-195.

Kira, I., Fawzi, M., Shuwiekh, H., Lewandowski, L., Ashby, J., \& Al Ibraheem, B. (2019b). Do adding attachment, oppression, cumulative, and proliferation trauma dynamics to PTSD criterion " $a$ " improve its predictive validity: Toward a paradigm shift? Current Psychology.Advanced online first. https://doi.org/10.1007/s12144019-00206-z.

Kira, I. \& Shuwiekh, H. (in press).Discrimination and mental health of Christians in Egypt: Coping trajectories and perceived posttraumatic growth. Mental Health, Religion, and Culture.

Kira, I., Shuwiekh, H., Al Ibraheem, B., \& Aljakoub, J. (2019d). Appraisals and emotion regulation mediate the effects of identity salience and cumulative stressors and traumas, on PTG and mental health: The case of Syrian's IDPs and refugees. Self and Identity: The journal of the International Society for Self and Identity, 18(3), 284-305.

Kira, I., Shuwiekh, H., Rice, K., Al Ibraheem, B., \& Aljakoub, J. (2017). A threatened identity: The mental health status of Syrian refugees in Egypt and its etiology. Identity: An International Journal of Theory and Research, 3, 176-190.

Kira, I., Shuwiekh, H., Rice, K., \& Ashby, J. (2018b). Is the "almost perfect scale" almost perfect? The psychometric properties of the Arabic version of APS-R and its short form. Psychology, 9, 18751897.

Kira, I.; Shuwiekh, H.; Rice, K.; Ashby, J; Elwakeel, S.; Sous, M.; Alhuwailah, A; Baali, S.; Azdaou, C.; Oliemat, E.\& Jamil, H. (2020b). Measuring COVID-19 as traumatic stress: Initial psychometrics and validation. Journal of Loss and Trauma: International Perspectives on Stress \& Coping.

Kira, I. A., Lewandowski, L., Templin, T., Ramaswamy, V., Ozkan, B., \& Mohanesh, J. (2008). Measuring cumulative trauma dose, types, and profiles using a development-based taxonomy of traumas. Traumatology, 14(2), 62-87.

Kira, I. A., Shuwiekh, H., Al-Huwailah, A. H., Lewandowski, L., Alawneh, A. W. N., Abou-Mediene, S., et al. (2019c). The central role of social identity in oppression, discrimination, and socialstructural violence: Collective identity stressors and traumas, their dynamics and mental health impact. Peace and Conflict: Journal of Peace Psychology, 25(3), 262-268.

Kira, I. A., Shuwiekh, H., Kucharska, J., Fawzi, M., Ashby, J. S., Omidy, A. Z., Abou-Mediene, S., \& Lewandowski, L. (2018a). Trauma proliferation and stress generation (TPSG) dynamics and their implications for clinical science. American Journal of Orthopsychiatry, 88(5), 582-596.

Kroenke, K., Spitzer, R. L., \& Williams, J. B. (2001). The PHQ-9: Validity of a brief depression severity measure. Journal of General Internal Medicine, 16(9), 606-613.

Kurzman, C., Fahmy, D. F., Gengler, J., Calder, R., \& Whitson, S. L. (2013). Arab winter. Contexts, 12(2), 12-21.

McKibbin, W., \& Fernando, R. (2020). The economic impact of COVID19. Economics in the Time of, COVID-19, 45.

Meng, B., Wang, J., Liu, J., Wu, J., \& Zhong, E. (2005). Understanding the spatial diffusion process of severe acute respiratory syndrome in Beijing. Public Health, 119(12), 1080-1087.

Ornell, F., Schuch, J. B., Sordi, A. O., \& Kessler, F. H. P. (2020). "Pandemic fear" and COVID-19: Mental health burden and strategies. Brazilian Journal of Psychiatry, 42(3), 232-235.

Palgi, Y., Shrira, A., Ring, L., Bodner, E., Avidor, S., Bergman, Y., Cohen-Fridel, S., Keisari, S., \& Hoffman, Y. (2020). The loneliness pandemic: Loneliness and other concomitants of depression, anxiety and their comorbidity during the COVID19 outbreak. Journal of Affective Disorders. Online first doi, 275, 109-111. https://doi.org/ 10.1016/j.jad.2020.06.036.

Palgi, Y., Shrira, A., \& Shmotkin, D. (2015). Aging with trauma across the lifetime and experiencing trauma in old age: Vulnerability and resilience intertwined. In K. E. Cherry (Ed.), Traumatic stress, and long-term recovery: Coping with disasters and other negative life events (p. 293-308). Springer International Publishing. https://doi. org/10.1007/978-3-319-18866-9 16.

Porcelli, P. (2020). Fear, anxiety, and health-related consequences after the COVID-19 epidemic. Clinical Neuropsychiatry: Journal of Treatment Evaluation, 17(2), 103-111.

Promislow, D. E. (2020). A geroscience perspective on COVID-19 mortality. The Journals of Gerontology: Series A., 75, e30-e33. https:// doi.org/10.1093/gerona/glaa094.

Robles, M. E., Badosa, J. M., Roig, A., Pina, B., \& Feixas Viaplana, G. (2009). La evaluación del estrés y del trauma:Presentación de la versión española de la escala de trauma acumulativo (CTS). Revista de Psicoterapia, 20(80), 89-104.

Rönnlund, M., Åström, E., Adolfsson, R., \& Carelli, M. G. (2018). Perceived stress in adults aged 65 to 90 : Relations to facets of time perspective and COMT val158Met polymorphism. Frontiers in Psychology, 9, 378.

Sawaya, H., Atoui, M., Hamadeh, A., Zeinoun, P., \& Nahas, Z. (2016). Adaptation and initial validation of the patient health questionnaire9 (PHQ-9) and the generalized anxiety disorder-7 questionnaire (GAD-7) in an Arabic speaking Lebanese psychiatric outpatient sample. Psychiatry Research, 239, 245-252.

Sayigh, R. (2013). On the exclusion of the Palestinian Nakba from the "trauma genre". Journal of Palestine Studies, 43(1), 51-60.

Schulze, K. E. (2016). The Arab-Israeli conflict. Taylor \& Francis.

Spitzer, R. L., Kroenke, K., Williams, J. B. W., \& Lowe, B. (2006). A brief measure for assessing generalized anxiety disorder. Archives of Internal Medicine, 166, 1092-1097.

Tabutin, D., Schoumaker, B., Rogers, G., Mandelbaum, J., \& Dutreuilh, C. (2005). The demography of the Arab world and the Middle East from the 1950 s to the 2000s. Population, 60(5), 505-615.

Tuite, A. R., Ng, V., Rees, E., Fisman, D., Wilder-Smith, A., Khan, K., \& Bogoch, I. I. (2020). Estimation of the COVID-19 burden in Egypt through exported case detection. The Lancet Infectious Diseases.

Usher, K., Bhullar, N., \& Jackson, D. (2020). Life in the pandemic: Social isolation and mental health. Journal of Clinical Nursing., 29, 2756 2757.

Walker, P. G., Whittaker, C., Watson, O. J., Baguelin, M., Winskill, P., Hamlet, A., ... \& Thompson, H. (2020). The impact of COVID-19 and strategies for mitigation and suppression in low-and middleincome countries. Science. https://doi.org/10.1126/science. abc0035, eabc0035. 
Wehrey, F. M. (2013). Sectarian politics in the Gulf: From the Iraq war to the Arab uprisings. Columbia University Press.

Williams, M. N., Grajales, C. A. G., \& Kurkiewicz, D. (2013). Assumptions of multiple regression: Correcting two misconceptions. Practical Assessment, Research, and Evaluation, 18(1), 11.

Zhou, F., Yu, T., Du, R., Fan, G., Liu, Y., Liu, Z., ... \& Guan, L. (2020b). Clinical course and risk factors for mortality of adult inpatients with COVID-19 in Wuhan, China: A retrospective cohort study. The lancet.
Zhou, X., Snoswell, C. L., Harding, L. E., Bambling, M., Edirippulige, S., Bai, X., \& Smith, A. C. (2020a). The role of telehealth in reducing the mental health burden from COVID-19. Telemedicine and $e$ Health, 26(4), 377-379.

Publisher's Note Springer Nature remains neutral with regard to jurisdictional claims in published maps and institutional affiliations. 